\title{
Information workflow proposal for integrating cost estimating, scheduling, and monitoring with BIM in SMEs
}

\author{
Proposta de fluxo de trabalho de informação para \\ integraçãoo de estimativa de custos, planejamento $e$ \\ monitoramento com BIM em PMEs
}

\author{
Mirian Caroline Farias Santos \\ Dayana Bastos Costa \\ Emerson de Andrade Marques Ferreira
}

${ }^{1}$ Mirian Caroline Farias Santos 'Universidade Federal da Bahia Salvador - BA - Brasil

2Dayana Bastos Costa ${ }^{2}$ Universidade Federal da Bahia Salvador - BA - Brasil

${ }^{3}$ Emerson de Andrade Marques

Ferreira

${ }^{3}$ Universidade Federal da Bahia

Recebido em 03/07/20 Aceito em 26/11/20 Salvador - BA - Brasil

Abstract lthough many studies have emphasized the benefits of the integration of Building Information Modeling (BIM), there is no consensus on the information workflow among main processes used in construction, particularly in small- and medium-size enterprises (SMEs). Therefore, this work proposes an information workflow that integrates 3D BIM modeling, cost estimating, scheduling, and monitoring processes in SMEs (ICSM Information Workflow). This research adopts the design science research approach, which includes (a) a literature review and a study of the information workflow among the processes, (b) a proposal of an information workflow based on certain assumptions for integration, (c) a participatory process for testing and adapting the proposed workflow, and (d) an evaluation of the proposed information workflow. The results indicate the participatory and cyclical processes that were proposed to define the work packages using a standard WBS and a database for information integration were the key for integrating people, technologies, and processes. The main contributions of this study are the proposal of an information workflow that integrates cost estimating, scheduling, and monitoring with BIM in SMEs, and the lessons learned based on the pilot test and evaluation of the ICSM Information Workflow in one of the two projects studied.

Keywords: BIM integration. Information workflow. Cost estimating. Scheduling. Monitoring. SMEs.

\section{Resumo}

Embora muitos estudos tenham enfatizado os benefícios da integração com BIM, não há consenso sobre um fluxo de trabalho da informação entre os principais processos inerentes à construção, principalmente para PMEs. Assim, este trabalho propõe um fluxo de trabalho de informação para integrar os processos de modelagem 3D BIM, estimativa de custos, planejamento e monitoramento em PMEs. Foi adotada a abordagem Design Science Research que inclui (a) revisão da literatura e estudo do fluxo de trabalho de informação entre os processos, (b) proposta de um fluxo de trabalho de informação baseado em alguns pressupostos de integração, denominado de ICSM, (c) teste e adaptação do fluxo de trabalho proposto, e (d) avaliação do fluxo de trabalho de informações proposto. Os resultados indicam que os processos participativos e cíclicos propostos para definir os pacotes de trabalho usando uma EAP padrão e um banco de dados para integração de informações foram fundamentais para a integração. As principais contribuições foram o fluxo de trabalho das informações do ICSM, e as lições aprendidas baseadas na avaliação do ICSM.

Palavras-chave: Integração BIM. Fluxo de trabalho de informações. Estimativa de custos. Planejamento. Monitoramento. PME.

SANTOS, M. C. F.; COSTA, D. B.; FERREIRA, E. de A. M. Information workflow proposal for integrating

v. 21, n. 2, p. 113-129, abr./jun. 2021.

ISSN 1678-8621 Associação Nacional de Tecnologia do Ambiente Construído.

http: //dx.doi.org/10.1590/s1678-86212021000200517 


\section{Introduction}

The construction industry suffers from poor communication among stakeholders, and thus, fragmentation due to the industry's dynamic characteristics, large number of disciplines, and various stages of project participants is a common problem (ALASHWAL; FONG, 2015; PREIDEL et al., 2016).

Building information modeling (BIM) is widely recognized as a possible solution that will bring all the information together and serve as a central data management system (PREIDEL et al., 2016). However, BIM alone cannot provide a permanent information management platform to alleviate the problems caused by fragmentation (CHEN; LU, 2019). Rather, it is necessary to have multidisciplinary teams with collaborative approaches to correct this problem (O'BRIEN, 2015).

Several studies have used BIM to facilitate the integration of planning and cost estimating processes (CHEN et al., 2013; SCHEER et al., 2014; FAN; WU; HUN, 2015; JRADE; LESSARD, 2015; FAN et al., 2016; WANG et al., 2016; D'AMICO et al., 2019; WANG et al., 2020; CEREZO-NARVÁEZ et al., 2020; among others). Of these studies, some have obtained successful results by solving integration issues and defining certain requirements, such as using a standard work breakdown structure (WBS) for a work package integrated model or suggesting a single platform for integration. However, due to the diversity of the enterprises and companies as well as the range of information technologies used, there is no consensus on the typical workflow for an integrated control system using BIM.

Furthermore, the discussion on how the integration of data, information, and knowledge can be achieved in small- and medium-sized projects is limited (REMPLING; KURUL; OTI, 2019). For these authors, this area, in particular, is important due to the considerable number of small- and medium-sized enterprises (SMEs) that form the supply chain of the architecture, engineering and construction (AEC) industries. In addition, due to the peculiar characteristics of SMEs, such as different organizational structures, smaller groups of workers, low capital to acquire new technologies, and little experience in BIM (POIRIER; STAUB-FRENCH; FORGUES, 2015), there are few studies on SMEs that focus on how to promote information management.

Therefore, this study proposes an information workflow to provide a better understanding of how to integrate BIM modeling, cost estimating, scheduling and monitoring processes in an SME in Brazil by identifying activities, information, and responsibilities. It also aims to identify requirements for the development of BIM models and BIM-related activities that result in the improvement in collaboration, transparency, and decision making among stakeholders. This paper contributes lessons learned based on implementing and evaluating the proposed information workflow for integrating these processes and activities in a pilot study.

\section{Integrated 3D modeling, cost estimation, and scheduling information workflow with bim}

Although cost estimating and scheduling processes share common data, such as resources, quantitative records and budgeted costs (CARR, 1993; FAN et al., 2016), this information is tracked separately primarily because it is generated and maintained by different people. The work packaging model (WPM) is the most comprehensive way to integrate cost and schedule data as it eliminates the need for a cost breakdown structure (CBS) and adds cost data to the WBS (CHO; RUSSELL; CHOI, 2013). The integration of the CBS and the WBS allows the construction of a matrix to map the progress of activities and the location of each element of the project (CEREZO-NARVÁEZ et al., 2020). This unified hierarchy of data storage, universal for each specialist, allows the specifics of each section of the project to be taken into account, thus resulting in the storage of structured data with less inconsistency and duplication of information (HONCHARENKO et al., 2020).

A critical problem in today's 3D BIM models is the discrepancy between the analytical structure of the element and the WBS of the project schedule (CEREZO-NARVÁEZ et al., 2020). Despite the BIM 4D capability to facilitate the team's generation of information, such as start and end dates of the elements and their criticality and visualization of the construction project over time (UMAR et al., 2015), the simulation requires multidisciplinary contributions, a significant project scope, and schedule information so project participants can develop and refine the modeling process (FISCHER et al., 2005; ISIKDAG; UNDERWOOD, 2010).

BIM models do not contain all the information necessary to produce a complete quantity take-off with just the 'click of a button' (NADEEM; WONG; WONG, 2015). Hence, the level of cost accuracy depends on the 
method used, the availability of data, and the definition of the project scope (JRADE, 2000). Furthermore, as specific quantities cannot be extracted directly from the models due to the tools' current capabilities, it is sometimes necessary for estimators to add missing information based on their knowledge and experience to produce the model (MONTEIRO; MARTINS, 2013; EASTMAN et al., 2011).

To guarantee integration and synchronization among computer management tools, especially in the scheduling and cost estimating systems using BIM, Jrade and Lessard (2015) highlight certain requirements:

(a) use of a single WBS standard;

(b) construction of the model according to the WBS;

(c) integration of different software, preferably software with automated connections, whenever possible;

(d) association of the time and cost data with each of the components of the model, allowing for quick and easy modification through automation;

(e) visualization as a communication tool among project stakeholders; and

(f) cost estimating and planning linked to a single platform.

Among these requirements, Hosseini et al. (2018) and Vidalakis, Abanda and Oti (2020) summarized barriers to the full implementation of BIM in SMEs: the lack of skills, knowledge and financial resources necessary for the high level of implementation, lack of interoperability between different platforms and proprietary files, and, difficulties associated with having a common language necessary for exchanging data in BIM environments.

\section{Research method}

This study adopted the design science research (DSR) approach that occurred during the interactive and cyclical process (from March 2016 to February 2018) based on the collaboration between the researcher and the project teams involved in two construction projects (Figure 1).

The DSR regulatory cycle described by Vaishnavi and Kuechler (2015) consists of the following stages:

(a) awareness of problem;

(b) suggestion;

(c) development;

(d) evaluation; and

(e) conclusion.

Figure 1 - Research method outline

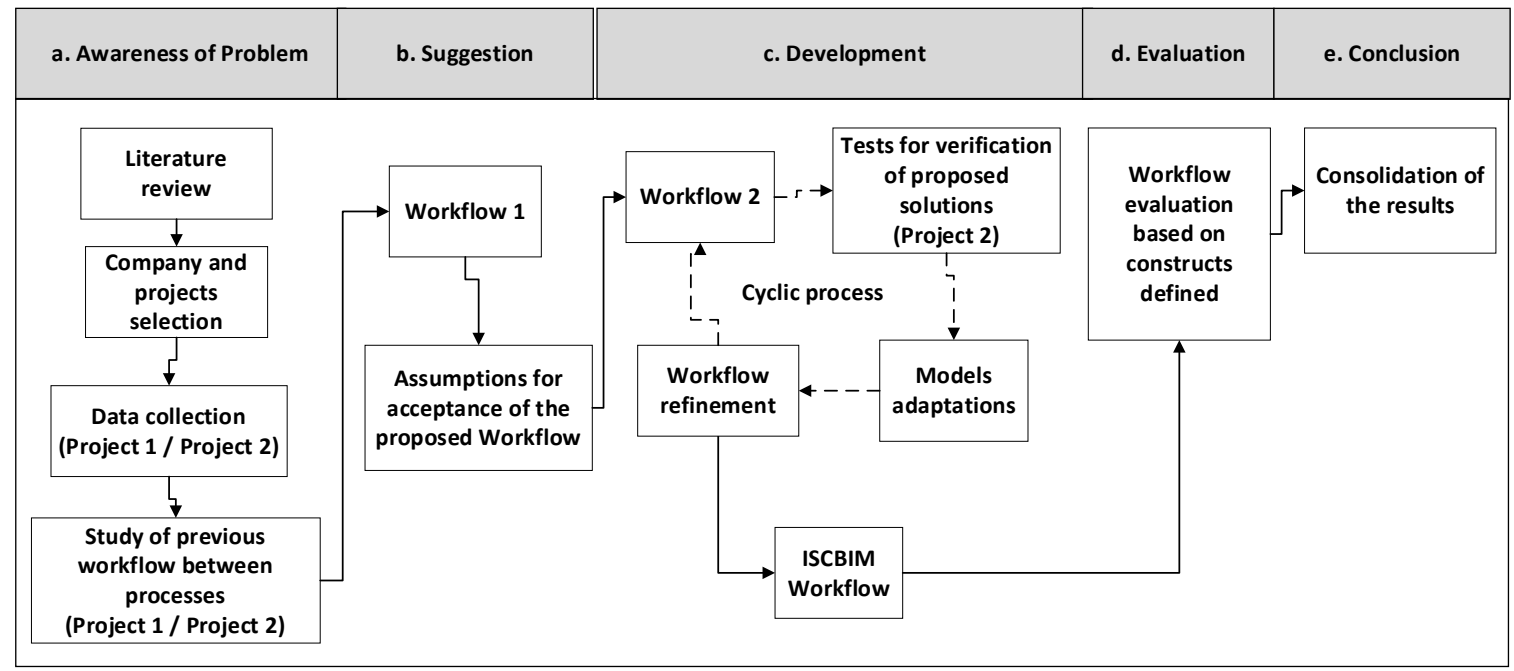

Note: *model adaptations. 
The Awareness of the problem stage aims to identify the research gap through a review of the literature, the selection of the construction company and projects, and the identification of the critical information workflow with respect to the four main processes studied: BIM 3D modeling, Scheduling, Cost estimating, and Monitoring. All other supporting processes in this study are referred to as secondary processes.

The literature review used the following keywords: integration, BIM, BIM 4D/5D, cost/estimation, and construction planning and control. Papers were searched on CAPES, a Brazilian database, and on SCOPUS, an international database.

The construction company selected for this study was at Level 2 early stage aiming at becoming a Level 3 with respect to maturity, based on the NBS 2014 classification (NATIONAL..., 2014), and had previously participated successfully in university involved research projects. Company A used Revit for BIM 3D modeling, Navisworks for 4D simulation, both of which are from Autodesk, a commercial software program called TOTVS for cost estimating, Microsoft Project and Microsoft Excel for scheduling, and a customized software called CPObras for on-site monitoring.

The study of the information workflow aimed to identify the responsible for the processes, software, type of information passed along the flow, and main obstacles to integrating the information among the main processes in Project 1 and Project 2.

Project 1 was a multi-residential housing complex with 500 apartment units distributed over 30 blocks and built using cast-in-place concrete walls. Project 2 was composed of 367 semi-detached, isolated singlefamily houses also built using cast-in-place concrete walls. Both projects were located in Salvador, Brazil.

For the information workflow data collection, the source of information included staff meetings and project visits with direct observations, as well as document analysis, i.e., 2D CAD projects, reports from construction monitoring software and BIM models. The primary tool used to represent the information throughout the workflow was a data flow diagram. Table 1 presents the description of the data collection in Project 1 and Project 2 with respect to the various research stages.

Table 1 - Description of data collection in Project 1 and Project 2 during each research stage

\begin{tabular}{|c|c|c|c|c|c|}
\hline \multirow[t]{2}{*}{ Activity } & \multirow[t]{2}{*}{ Participant } & \multirow[t]{2}{*}{ Data collected } & \multirow[t]{2}{*}{ Environment } & \multicolumn{2}{|c|}{$\begin{array}{c}\text { Duration of interview } \\
\text { (h) }\end{array}$} \\
\hline & & & & Project 1 & Project 2 \\
\hline \multirow{4}{*}{$\begin{array}{l}\text { Awareness } \\
\text { of Problem }\end{array}$} & Manager & $\begin{array}{l}\text { Interviews about routines and } \\
\text { processes (cost estimating, } \\
\text { scheduling and monitoring) } \\
\text { developed by the company }\end{array}$ & \multirow[t]{2}{*}{ Office } & 2 & 3 \\
\hline & Intern (modeler) & $\begin{array}{l}\text { Interviews about routines and } \\
\text { processes (modeling) developed } \\
\text { by the company }\end{array}$ & & 4 & 6 \\
\hline & Field Engineer & $\begin{array}{l}\text { Interviews about routines and } \\
\text { processes (monitoring) } \\
\text { developed by the } \\
\text { company/observations of field } \\
\text { activities }\end{array}$ & \multirow[t]{2}{*}{ Field } & 8 & 20 \\
\hline & $\begin{array}{l}\text { Planning } \\
\text { Engineer }\end{array}$ & $\begin{array}{l}\text { Interviews about routines and } \\
\text { processes (scheduling) } \\
\text { developed by the company }\end{array}$ & & 3 & 3 \\
\hline \multirow{4}{*}{$\begin{array}{l}\text { Suggestion } \\
\text { and } \\
\text { Developme } \\
\text { nt }\end{array}$} & Manager & \multirow{4}{*}{$\begin{array}{l}\text { Meetings to discuss development } \\
\text { and adjustments of the } \\
\text { information workflow }\end{array}$} & \multirow{3}{*}{ Office } & & 30 \\
\hline & Intern (modeler) & & & - & 50 \\
\hline & Consultant & & & & 30 \\
\hline & Field Engineer & & Field & - & 6 \\
\hline \multirow{5}{*}{$\begin{array}{l}\text { Evaluation } \\
\text { and } \\
\text { Conclusion }\end{array}$} & Manager & Interviews and discussions & \multirow{3}{*}{ Office } & & 5 \\
\hline & Intern (modeler) & $\begin{array}{l}\text { related to the information } \\
\text { workflow implementation/ } \\
\text { surveys }\end{array}$ & & - & 6 \\
\hline & Intern (estimator) & \multirow{3}{*}{ Survey administration } & & & 1 \\
\hline & Field Engineer & & \multirow[b]{2}{*}{ Field } & - & 1 \\
\hline & $\begin{array}{l}\text { Planning } \\
\text { Engineer }\end{array}$ & & & & 1 \\
\hline
\end{tabular}


Based on the data collected and the literature review, the practical problem identified was the lack of process, people and software integration; poor communications; and inefficient workflow among activities and information related to BIM modeling, Cost estimating, Scheduling, and Monitoring processes.

The Suggestion stage involves the proposition of artifacts based on the configuration of new or existing elements (VAISHNAVI; KUECHLER, 2015). Thus, based on the requirements listed by Jrade and Lessard (2015) and on the problems identified in the information workflow study of Project 1 and Project 2, the artifact proposed in this study is an information workflow for integrating the activities concerning the four main processes being examined. The information workflow proposed aimed at integrating activities, people, and software in each one of the processes from the office to the field. Accordingly, the first workflow proposed (Workflow 1) focused on the integration of the software used by Construction Company A.

In this stage, a conceptual framework (Figure 2) was established that included a set of assumptions to support the prescription of Information Workflow 1, which was developed based on the literature review and the information workflows collected from Projects 1 and 2. The four assumptions established were:

(a) 3D BIM/Cost estimating integration;

(b) Scheduling/Monitoring integration;

(c) 3D BIM/Scheduling/Monitoring integration; and

(d) Cost estimating/Scheduling/Monitoring integration.

Thus, with respect to the elaboration of the four propositions, the assumption was that the integration of processes should be conducted one by one, thus adopting the pillars of knowledge management, i.e., people, processes, and technology, as a fundamental basis, and the integration should occur using the WBS as a standard parameter. A discussion on the conceptual framework is presented in the work of Santos, Costa and Ferreira (2021).

In the Development stage, as a result of the analysis of Information Workflow 1 and the established four assumptions established, Information Workflow 2 was developed. In this stage, a cyclical process of testing and adapting the software and additional tools, such as tables, reports, and codifications for Project 2 , occurred. Examples of the adjustments developed during the development stage include a better definition of the project's WBS, improvements in the scheduling spreadsheets, changes in the exportation data between software, and explanations of the criteria for choosing mobile applications. The product of the development stage was the Information Workflow 3 process, i.e., the ICSM Information Workflow process (Integrated Cost Estimating, Scheduling, and Monitoring Information Workflow).

Figure 2 - Conceptual framework and assumptions

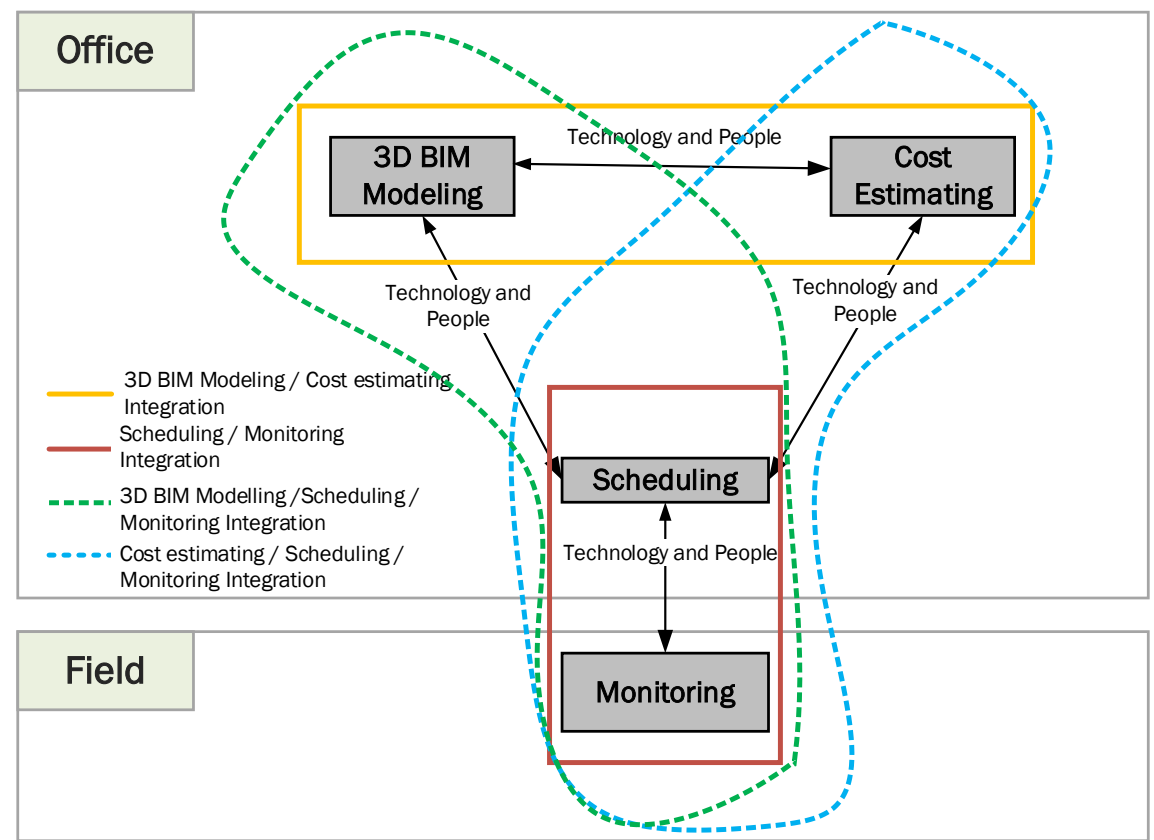

Source: Santos, Costa and Ferreira (2021). 
The Evaluation and Conclusion stage consisted of testing the ICSM Information Workflow process in Project 2 over an eight-week period, from December 2017 to January 2018, in Project 2. The test included the Scheduling / Monitoring integration as the construction phase was already in progress. During this stage, data collection involved interviews and discussion related to the implementation of the ICSM Information Workflow and the administration of a survey to be completed by the manager, modeler, estimator, field engineer, and planning engineer (Table 1).

Based on the literature review, four constructs were established to evaluate the ICSM Information Workflow. The first was the integration of the workflow, which measured whether the information workflow worked appropriately according to the assumptions previously established (Figure 2) and based on the set of requirements established by Jrade and Lessard (2015) and presented in Section 2. The explanations of the other three constructs are based on some criteria to evaluate artifacts by March and Smith (1995): usefulness and limitations, ease of use, and generalization and replicability, using results obtained in the study and on users' perceptions. Table 2 presents the description of each of the constructs, variables, and sources of evidence adopted in this study. These variables resulted from the problems and needs observed in the study of Project 1 and Project 2's information workflows of Company A.

The evaluation of the ICSM Information Workflow consisted of data obtained from five interviews, i.e., one each with the manager, intern (modeler), trainee estimator, planning engineer, and field engineer, and data from literature review. The interviews were conducted via a survey consisting of open-ended questions and structured questions based on a scale that ranged from 1 to 5 ( 1 - totally disagree; 2 - partially disagree; 3 neither agree nor disagree; 4 - partially agree; 5 - totally agree).

Table 2 - Constructs, variables and sources of evidence

\begin{tabular}{|c|c|c|c|}
\hline Construct & Definition & Variable & Source of evidence \\
\hline $\begin{array}{l}\text { Integration of } \\
\text { workflow }\end{array}$ & $\begin{array}{l}\text { Seeks to evaluate the } \\
\text { extent to which the } \\
\text { proposed workflow } \\
\text { integrates the cost } \\
\text { estimating, BIM } \\
\text { modeling, scheduling } \\
\text { and monitoring } \\
\text { processes between } \\
\text { the field and office }\end{array}$ & $\begin{array}{l}\text { Integration of different software } \\
\text { and tools } \\
\text { Use of a standard WBS among the } \\
\text { processes } \\
\text { Communication between office } \\
\text { and field } \\
\text { Review and update of the } \\
\text { information } \\
\text { Automation and simplification of } \\
\text { the processes } \\
\text { Single database and easy access to } \\
\text { information }\end{array}$ & $\begin{array}{l}\text { Analysis of documents, } \\
\text { interviews, participant } \\
\text { observation, users' } \\
\text { perception, data } \\
\text { collected during } \\
\text { meetings }\end{array}$ \\
\hline $\begin{array}{l}\text { Usefulness and } \\
\text { limitations }\end{array}$ & $\begin{array}{l}\text { Aims to assess } \\
\text { whether the } \\
\text { workflow is useful } \\
\text { from the perception } \\
\text { of those involved }\end{array}$ & $\begin{array}{l}\text { Providing information needed for } \\
\text { the users } \\
\text { Benefits of implementation } \\
\text { Limitations of implementation }\end{array}$ & $\begin{array}{l}\text { Analysis of documents, } \\
\text { interviews, participant } \\
\text { observations, data } \\
\text { collected during } \\
\text { meetings, } \\
\text { users' perceptions } \\
\end{array}$ \\
\hline Ease of use & $\begin{array}{l}\text { Aims to assess } \\
\text { whether users can } \\
\text { easily use the } \\
\text { workflow }\end{array}$ & $\begin{array}{l}\text { Ease of use of the workflow and } \\
\text { software/system tools } \\
\text { Ease of understanding the } \\
\text { information provided } \\
\text { Learning about the workflow and } \\
\text { tools used }\end{array}$ & $\begin{array}{l}\text { Users' perceptions and } \\
\text { participant observations }\end{array}$ \\
\hline $\begin{array}{l}\text { Generalization } \\
\text { and replicability }\end{array}$ & $\begin{array}{l}\text { Aims to assess } \\
\text { whether other types } \\
\text { of projects can use } \\
\text { the workflow }\end{array}$ & $\begin{array}{l}\text { Use of standardized encoding and } \\
\text { flow of information } \\
\text { Adaptation of the workflow and } \\
\text { tools to other companiess projects } \\
\text { Adaptation of the workflow and } \\
\text { tools to other external contexts }\end{array}$ & $\begin{array}{l}\text { Document analyses and } \\
\text { participant observations }\end{array}$ \\
\hline
\end{tabular}




\section{Results}

\section{Awareness of Problem: studying Project 1 and Project 2 information workflow}

In a previous work, Santos, Costa and Ferreira (2021) discussed the main problems found in Project 1 and Project 2 regarding the company object of this study. The identified problems are summarized as follows.

When associating the results with the requirements highlighted by Jrade and Lessard (2015), although the construction of the BIM model occurred according to a WBS, there was no use of a single WBS standard, making challenging to control the project costs and time in both the field and office environments.

The lack of integration among the different software did not provide effective coordination and communication among the teams, mostly because there was not a single controllable parameter or tool to integrate all the construction professionals and make the data available to everyone, as recommended by Cho, Russel and Choi (2013).

When the real project data returned to the office, the information was fragmented or grouped, and thus, the team had to spend time compiling and understanding it. This fragmentation happened mostly due to the failure to define the work package based on field-planned activities, through cost estimating, BIM modeling, and scheduling processes.

The field and the office teams' communication had drawbacks with respect to the quality of information due to the excessive manual activities required to complete the monitoring reports and the frequency of submission (monthly). Furthermore, this lack of communication did not allow for rapid intervention or for deviations from the planned goals related to costs and schedules.

According to the results, some of the problems associated with using BIM in SMEs as reported by Hosseini et al. (2018) are evident, such as:

(a) shortage of skills and expertise for high level of BIM implementation;

(b) perception of limited functionality of high levels of higher BIM because, even though the company used BIM, it was unable to transition from level 2 to level 3;

(c) the immaturity of BIM technology to support high levels of BIM implementation, because the software used did not exchange information between the studied processes;

(d) the perceived low benefits of BIM, once the BIM model was left unused in the office; and

(e) the perceived lack of suitability of BIM for all types of construction projects, because the projects exhibited different characteristics, albeit they did not experience the BIM benefits in the same way.

\section{Suggestion and development: ICSM information workflow}

The ICSM Information Workflow describes the activities, technologies, and people involved in the integration of the 3D BIM modeling, Cost estimating, Scheduling, and Monitoring processes.

The structure of the ICSM Information Workflow (Figure 3) presents the four phases, which represent the various groups of activities developed for a common purpose, namely:

(a) the geometry and work package definition participatory phase, represented by the green lines and arrows;

(b) the integrated BIM model elaboration phase, represented by the dark blue lines and arrows;

(c) the monitoring and control phase, represented by the light blue lines and arrows; and

(d) the integrated BIM model updating phase, represented by the orange lines and arrows.

\section{Geometry and work package definition participatory phase}

In this phase, the BIM modeler, the planning engineer, the field engineer and the cost estimating team exchange information in a participatory and cyclical process to define the work packages to be used for planning and controlling the activities in the office and in the field. This discussion aids in defining the level of detail of the BIM 3D model and assists in defining the standard WBS that will be used by the cost estimating, planning, and monitoring teams. The use of a standard WBS throughout the processes facilitates 
the communication between the software and the additional tools adopted and also facilitates communications because all of the parties responsible for the processes understand it.

\section{Integrated BIM model elaboration phase}

During this phase, the Integrated BIM Model is created. It is a model that contains all the geometry, planning, and cost estimating information from modeling, 4D simulation, planning and cost estimate software. The Integrated BIM Model makes it possible for all the information to be available in one model and reviewed and updated. The creation of the 4D simulation environment is accomplished by associating cost and planning data in the Cost and Schedule Integrated Spreadsheet using the WBS as a standard language. The Cost and Schedule Integrated Spreadsheet is responsible for integrating the as-planned and real data of schedules and costs and linking the data to the integrated BIM model through the BIM integration software using the WBS (Figure 4). The BIM integration software, in this case, is the 4D simulation software, but it can be anyone that can centralize geometric, cost and schedule information. The Integrated BIM Model can help teams using 4D/5D simulations by evaluating alternative construction scenarios. This model is available for both office and field usage because it supports planned and real data.

Figure 3 - ICSM Information Workflow

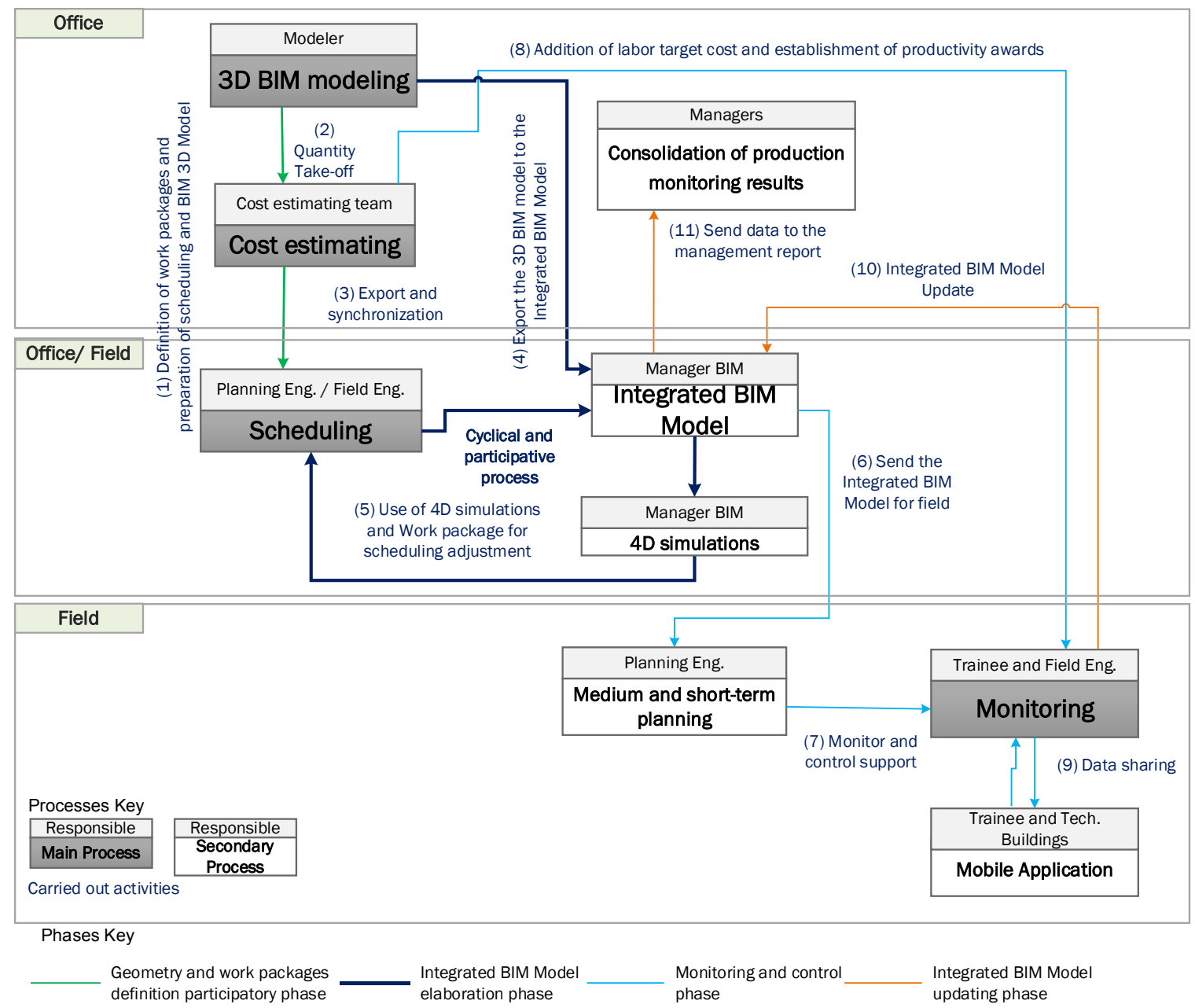

Note: *geometry and work packages' (work package)definition participatory phase. 


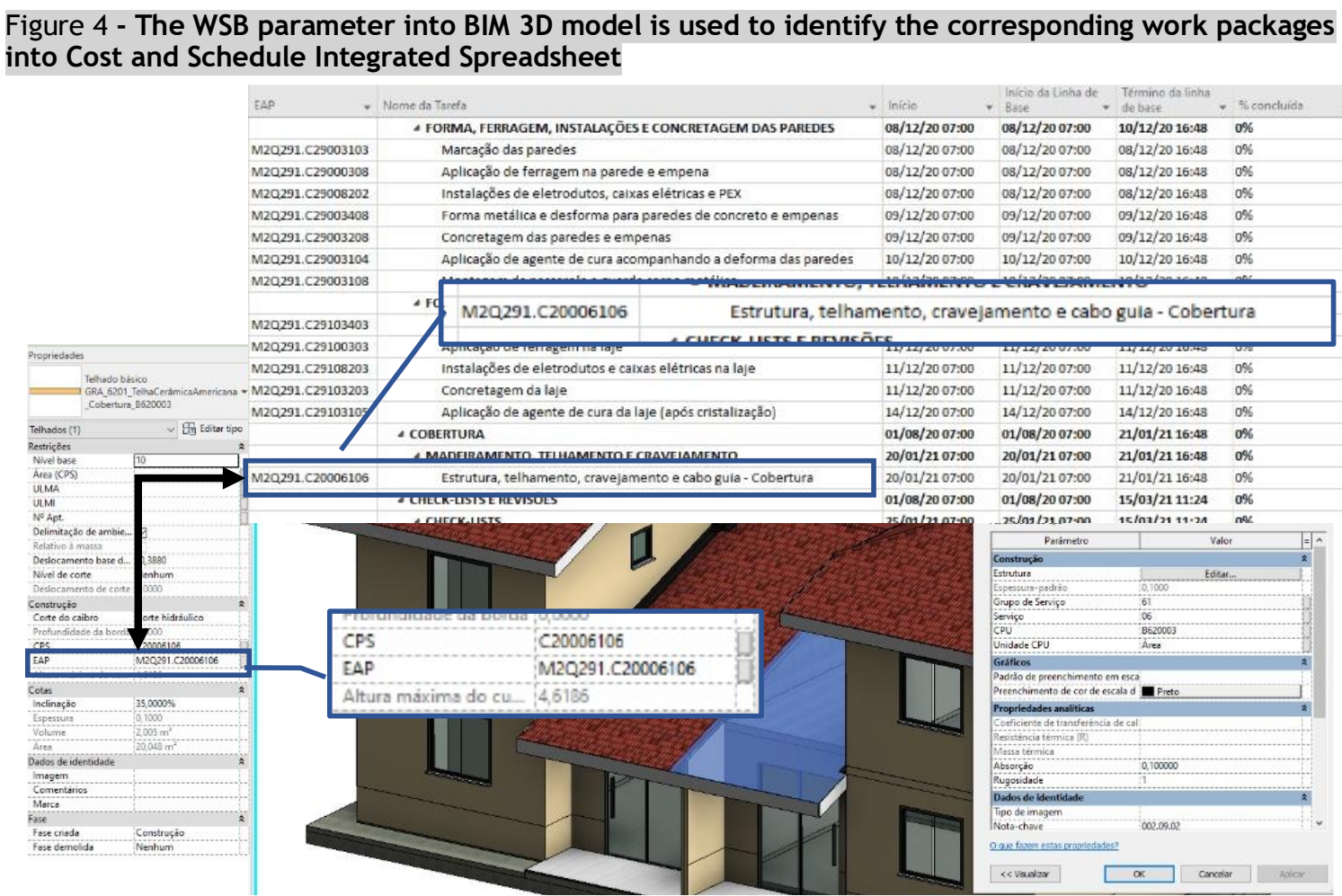

\section{Monitoring and control phase}

This phase encompasses monitoring and control activities through the definition of actions related to medium- and short-term planning, i.e., identification of constraints, definitions of work labor teams, and explanations of work sequences. In this phase, there is a monitoring software and a mobile application to access and update the Integrated BIM Model with schedule and cost information. At this stage, the field team directly collects the planned data using a remote access application, a mobile application, or the monitoring software in the Cost and Schedule Integrated Spreadsheet. This spreadsheet contains planning information, such as work packages from the standard WBS, the resource and cost information from the cost estimating software, and the monitoring information, such as the real dates and cost data of each work package.

\section{Integrated BIM Model updating phase}

In this phase, the real data of each work package from the Cost and Schedule Integrated Spreadsheet are entered into the Integrated BIM Model and are used to track progress reports to aid decision making.

Table 3 presents a brief description of the activities developed in the ICSM Information Workflow.

The analysis of the existing (as is) process indicates that the planning and cost estimating teams can use the BIM model to enhance the accuracy of quantitative surveys and simulations and thereby facilitate planning visualization. The proposed workflow also encourages the collaboration between field and office teams as they define the work packages that compose the WBS given that a standardized WBS that remains the same throughout the processes studied, promotes integration between the two fields. Furthermore, while the ICSM Information Workflow proposes the integration of planned data with actual data (cost and dates) in the field, it does not make any progress in integrating long term planning with medium- and short-term planning.

\section{Evaluation: analyzing the ICSM information workflow}

A pilot test of the ICSM Information Workflow was performed in Project 2 that addressed the integration between scheduling and monitoring processes. It was only a pilot because the construction phase was already in progress, and updates to the BIM model did not follow construction progress. 
Table 3 - Description of activities developed in the ICSM Information Workflow

\begin{tabular}{|c|c|c|}
\hline No & Activities & Description \\
\hline \multicolumn{3}{|c|}{ Geometry and work package definition participatory phase } \\
\hline 1 & $\begin{array}{l}\text { Definition of work packages } \\
\text { and preparation of scheduling } \\
\text { and BIM 3D model }\end{array}$ & $\begin{array}{l}\text { Modeling and scheduling/monitoring teams define the work } \\
\text { packages that will aid BIM 3D modeling and long-term } \\
\text { planning. }\end{array}$ \\
\hline 2 & Quantity take-off & $\begin{array}{l}\text { Quantitative take-off is conducted based on the BIM 3D model } \\
\text { and sent to the cost estimating team. }\end{array}$ \\
\hline 3 & Export and synchronization & $\begin{array}{l}\text { Cost data are exported and synchronized with the Cost and } \\
\text { Schedule Integrated Spreadsheet. }\end{array}$ \\
\hline \multicolumn{3}{|c|}{ Integrated BIM Model elaboration phase } \\
\hline 4 & $\begin{array}{l}\text { Export the 3D BIM model to } \\
\text { the integrated BIM model }\end{array}$ & $\begin{array}{l}\text { BIM 3D model is exported to BIM Integration software to } \\
\text { initiate the Integrated BIM Model. }\end{array}$ \\
\hline 5 & $\begin{array}{l}\text { Use of } 4 \mathrm{D} \text { simulations and } \\
\text { work package for scheduling } \\
\text { adjustment }\end{array}$ & $\begin{array}{l}\text { Cost and Schedule Integrated Spreadsheet is exported to BIM } \\
\text { integration software to link with BIM 3D. Simulations assist } \\
\text { the adjustment of work packages. }\end{array}$ \\
\hline \multicolumn{3}{|c|}{ Monitoring and control phase } \\
\hline 6 & $\begin{array}{l}\text { Sending the integrated BIM } \\
\text { model for field }\end{array}$ & $\begin{array}{l}\text { Integrated BIM Model and Cost and Schedule Integrated } \\
\text { Spreadsheet are sent to the field to support medium- and short- } \\
\text { term planning. }\end{array}$ \\
\hline 7 & $\begin{array}{l}\text { Monitoring and control } \\
\text { support }\end{array}$ & $\begin{array}{l}\text { Medium- and short-term planning support control integrated } \\
\text { into monitoring software. }\end{array}$ \\
\hline 8 & $\begin{array}{l}\text { Addition of labor target cost } \\
\text { and establishment of } \\
\text { productivity awards }\end{array}$ & $\begin{array}{l}\text { Labor target cost is added to monitoring software to control } \\
\text { labor costs and productivity awards. }\end{array}$ \\
\hline 9 & Data sharing & $\begin{array}{l}\text { Field teams access integrated BIM model and Cost and } \\
\text { Schedule Integrated Spreadsheet. }\end{array}$ \\
\hline \multicolumn{3}{|c|}{ Integrated BIM Model updating phase } \\
\hline 10 & Integrated BIM model Update & $\begin{array}{l}\text { Cost and Schedule Integrated Spreadsheet is updated with real } \\
\text { schedule data, which then updates the Integrated BIM Model. }\end{array}$ \\
\hline 11 & $\begin{array}{l}\text { Sending data to the } \\
\text { management report }\end{array}$ & $\begin{array}{l}\text { The management report is made based on Cost and Schedule } \\
\text { Integrated Spreadsheet. }\end{array}$ \\
\hline
\end{tabular}

The ICSM Information Workflow evaluation involved the analysis of the following constructs: the integration, usefulness, limitations, ease of use, and generalization and replicability. As a result of this evaluation, a set of lessons learned were identified as the focus for application of the workflow in an SME.

\section{Integration of the information workflow}

Table 4 presents the results of the evaluation of the five users interviewed who indicated, on a scale from 1 to 5 , the degree to which they agree with the integration of the workflow between processes. For this evaluation, they had to consider a matrix with four assumptions adopted in the conceptual framework and the variables presented in Table 2.

The participants also indicated their level of participation in the development of the workflow. The results were as follows: Participant A (planning engineer) exhibited low involvement, Participant B (field engineer) exhibited moderate involvement, Participant C (intern estimator) exhibited low involvement, Participant D (intern BIM modeler) and Participant E (manager) exhibited very high involvement.

The interviewees awarded the variable use of a standard WBS among processes with very high scores especially with respect to the $3 \mathrm{D} \mathrm{BIM} /$ scheduling/monitoring integration. However, the Cost estimating/Scheduling and Monitoring integration process received the respondents' lowest scores because the company chose to control the cost independent of the cost and schedule integrated spreadsheet. The use of a standard WBS overcomes one of barriers to the full implementation of BIM in SMEs identified in the literature (HOSSEINI et al., 2018; VIDALAKIS; ABANDA; OTI, 2020). It should be developed first, followed by research on work packages with interested parties to establish the level of the project scope (WANG et al., 2020), making sure to include not only the physical structure of the project but also the management elements (CEREZO-NARVÁEZ et al., 2020). 
The interviewees acknowledged an improvement in communication between the field and office teams regarding Scheduling/Monitoring integration. The re-planning meetings and the consistency between the work package definitions and their performance field contributed to the improvement. The early detection of inconsistencies and delays encouraged the teams to communicate via e-mail and telephone to resolve the identified problems. However, only the office team agreed about the integration between 3D BIM/Cost estimation, as they had the opportunity to put into practice the use of cost estimation based on BIM. This is a common problem when working with BIM, as the interactions between departments can take a long time when working on BIM technologies (HONCHARENKO et al., 2020). In addition, the low perception of benefits is one of the problems associated with using BIM in SMEs according to Hosseini et al. (2018).

With respect to the variable integration of different software and tools, all interviewees agreed that the integration of the scheduling and monitoring software had been successfully achieved. However, the 3D $\mathrm{BIM} /$ Cost estimating integration, even with no significant differences, received a lower score. One of the estimators complained that even with an automatic take-off routine, there is a need to group and ungroup the information to use it in cost estimations. Respondents also noted that the amount of software used was substantial and suggested that it could be reduced, a finding that corroborated that of Vidalakis, Abanda and Oti (2020).

Table 4 - Evaluation of the integration of information flow between processes

\begin{tabular}{|c|c|c|c|c|c|c|c|}
\hline \multirow{2}{*}{\multicolumn{2}{|c|}{$\begin{array}{l}\text { Integration of } \\
\text { information flow } \\
\text { among processes }\end{array}$}} & \multicolumn{6}{|c|}{ Variables } \\
\hline & & \multirow{2}{*}{$\begin{array}{c}\text { Use of } \\
\text { WBS } \\
\text { among } \\
\text { processes }\end{array}$} & \multirow{2}{*}{$\begin{array}{l}\text { Communi- } \\
\text { cation } \\
\text { between } \\
\text { office and } \\
\text { field }\end{array}$} & \multirow{2}{*}{$\begin{array}{c}\text { Integration } \\
\text { of different } \\
\text { software and } \\
\text { tools }\end{array}$} & \multirow{2}{*}{$\begin{array}{c}\text { Review and } \\
\text { update of } \\
\text { the } \\
\text { information }\end{array}$} & \multirow{2}{*}{$\begin{array}{c}\text { Automation } \\
\text { and } \\
\text { simplification } \\
\text { of the } \\
\text { processes }\end{array}$} & \multirow{2}{*}{$\begin{array}{c}\text { Single } \\
\text { database } \\
\text { and easy } \\
\text { access to } \\
\text { information }\end{array}$} \\
\hline & Scale & & & & & & \\
\hline \multirow{5}{*}{$\begin{array}{l}\text { 3D BIM/ } \\
\text { Scheduling/ } \\
\text { Monitoring }\end{array}$} & 1 & & & & & & \\
\hline & 2 & & & & $\mathrm{~B}, \mathrm{D}$ & A, B & \\
\hline & 3 & & $\mathrm{D}, \mathrm{E}$ & $\mathrm{D}$ & & $\mathrm{D}$ & $\mathrm{B}$ \\
\hline & 4 & $\mathrm{~B}, \mathrm{C}$ & $\mathrm{B}, \mathrm{C}$ & & $\mathrm{A}$ & $E$ & $\mathrm{D}, \mathrm{E}$ \\
\hline & 5 & $\mathrm{~A}, \mathrm{D}, \mathrm{E}$ & A & $\mathrm{A}, \mathrm{B}, \mathrm{C}, \mathrm{E}$ & $\mathrm{C}, \mathrm{E}$ & $\mathrm{C}$ & $\mathrm{A}, \mathrm{C}$ \\
\hline \multirow{5}{*}{$\begin{array}{l}\text { Scheduling/ } \\
\text { Monitoring }\end{array}$} & 1 & & & & & & \\
\hline & 2 & & & & $\mathrm{~B}$ & $\mathrm{~A}, \mathrm{~B}$ & \\
\hline & 3 & $\mathrm{D}$ & $\mathrm{D}$ & & & & B \\
\hline & 4 & B & $\mathrm{B}, \mathrm{C}$ & & A & $\mathrm{E}$ & $\mathrm{E}$ \\
\hline & 5 & $\mathrm{~A}, \mathrm{D}, \mathrm{E}$ & $\mathrm{A}, \mathrm{E}$ & $\mathrm{A}, \mathrm{B}, \mathrm{C}, \mathrm{D}, \mathrm{E}$ & $\mathrm{C}, \mathrm{D}, \mathrm{E}$ & $\mathrm{C}, \mathrm{D}$ & $\mathrm{A}, \mathrm{C}, \mathrm{D}$ \\
\hline \multirow{5}{*}{$\begin{array}{l}\text { Cost } \\
\text { estimating/ } \\
\text { Scheduling } \\
\text { and } \\
\text { Monitoring }\end{array}$} & 1 & & & & & & \\
\hline & 2 & & $\mathrm{C}$ & & $\mathrm{B}, \mathrm{D}$ & $\mathrm{A}, \mathrm{B}$ & \\
\hline & 3 & $\mathrm{D}$ & & $\mathrm{D}$ & $\mathrm{C}$ & & B \\
\hline & 4 & $\mathrm{~B}, \mathrm{C}$ & $\mathrm{B}, \mathrm{D}$ & & A & $\mathrm{D}, \mathrm{E}$ & $\mathrm{D}, \mathrm{E}$ \\
\hline & 5 & $\mathrm{~A}, \mathrm{E}$ & $\mathrm{A}, \mathrm{E}$ & $\mathrm{A}, \mathrm{B}, \mathrm{C}, \mathrm{E}$ & $\mathrm{E}$ & $\mathrm{C}$ & $\mathrm{A}, \mathrm{C}$ \\
\hline \multirow{5}{*}{$\begin{array}{l}\text { 3D BIM/Cost } \\
\text { estimating }\end{array}$} & 1 & & $\mathrm{D}$ & & & & \\
\hline & 2 & & & & & A & \\
\hline & 3 & B & $\mathrm{B}, \mathrm{C}, \mathrm{E}$ & B & $\mathrm{B}, \mathrm{D}$ & B & B \\
\hline & 4 & $\mathrm{D}$ & & $\mathrm{D}$ & A & $\mathrm{E}$ & $\mathrm{D}, \mathrm{E}$ \\
\hline & 5 & $\mathrm{~A}, \mathrm{C}, \mathrm{E}$ & A & $\mathrm{A}, \mathrm{C}, \mathrm{E}$ & $\mathrm{C}, \mathrm{E}$ & $\mathrm{C}, \mathrm{D}$ & $\mathrm{A}, \mathrm{C}$ \\
\hline \multicolumn{8}{|c|}{$\begin{array}{l}\text { Note: } \\
\text { 1-totally disagree; } \\
\text { 2- partially disagree; } \\
\text { 3- neither agree nor disagree; } \\
\text { 4- partially agree; and } \\
\text { 5- totally agree. } \\
\text { A - Planning Engineer; } \\
\text { B - Field Engineer; } \\
\text { C - Intern (estimator); } \\
\text { D - Intern (modeler); and } \\
\text { E - Manager. }\end{array}$} \\
\hline
\end{tabular}


As the BIM software packages currently available for the AEC sector are numerous, many applications have been adapted for a specific purpose according to the needs for which they were developed (VIDALAKIS; ABANDA; OTI, 2020). To facilitate the integrated workflow, some advances are beginning to appear in the AEC industries, and software companies are migrating their technologies to the cloud and providing new ways to interface with the information generated by their tools. However, the high price for purchasing the corresponding software products (HONCHARENKO et al., 2020) can be an obstacle for SMEs that have low capital to acquire new technologies and little experience in BIM (POIRIER; STAUB-FRENCH; FORGUES, 2015).

The users' perception the revision and updating of the information indicated that Scheduling/Monitoring integration receive the best evaluation. Although the frequency of updating information meets the needs of most users, the delay in updating data for the monitoring software was one of the users' recurring complaints; thus, there is a need for faster updating in terms of the progress of the construction services. Cost estimating/Scheduling and Monitoring integration received the lowest scores because the company chose not to integrate cost into Monitoring.

The automation and simplification of processes received the worst evaluation by users, primarily because of an excess of necessary software, except for the 3D BIM/Cost estimating integration, which obtained a better evaluation due to the automatic quantitative take-off that BIM provides. This result is because the cost estimate information was based on the model information, which facilitated the automatic exchange of information and documents (XU; MA; DING, 2014), although the automation of quantity take-off is often difficult due to the accuracy of the BIM models and the various modeling methods (SARIDAKI; PSARRA; HAUGBØLLE, 2019).

Other criterion that received high marks from the users was the single database and access to information concerning Scheduling/Monitoring integration because it was possible to create monitoring reports. The benefit of a single database to facilitate integration was also discussed in previous studies (JRADE; LESSARD, 2015; PARK; CAI, 2017). This criterion was the least noticed by the field engineer because he did not have direct access to the cost and schedule integrated spreadsheet. Rather, his access was via reports sent from the office to the field. This lack of access was due to little capital to acquire software licenses by the company. This constitutes another limitation for the use of BIM in SMEs (POIRIER; STAUB-FRENCH; FORGUES, 2015).

Another alternative highlighted in the literature is to centralize and access the data through federated models of two approaches. The first is a proprietary approach that supports multiple heterogeneous file format readers who map their own managed data structure. However, this way of integration is limited to supporting a heterogeneous environment, where models from multiple sources can be federated into one based on spatial co-location, and little else. Thus, it requires human intervention to deal with the results (SOLIHIN; EASTMAN; LEE, 2016). The second approach is the use of database servers, a neutral platform that can be connected to any type of application based on BIM (PREIDEL et al., 2016). This allows users to host their own BIM server to centralize information of any construction or other project related to construction (JIANG et al., 2012). However, companies are reluctant to adopt cloud-based solutions due to concerns about data security and privacy (REZGUI; BEACH; RANA, 2013).

\section{Usefulness and limitations}

Table 5 presents the users' perceptions of the benefits and barriers to the implementation of the proposed workflow. The information makes it possible to identify lessons learned from the pilot implementation.

\section{Table 5 - Benefits and barriers to implementation of ICSM Information Workflow}

\begin{tabular}{|l|l|}
\hline \multicolumn{1}{|c|}{ Benefits } & \multicolumn{1}{c|}{ Limitations } \\
\hline - Macro planning view for faster decision making & $\bullet$ Work package changes made in the field \\
- Control of cost and planning targets & - Delay in the upload of data, which may \\
- Better integration between cost and planning & not represent what is occurring in the field \\
through work packages & $\bullet$ Weak integration between office and field \\
- Unified standard code & \\
- Less time spent on compatibilization and revision & \\
\hline
\end{tabular}


As Project 2 did not include long-term planning, the participants noted a significant improvement in the macro view of planning and cost control resulting in faster decision making and better control of cost and planning targets. This improvement is because the implementation of the digital technologies increased the speed of decision making and the quality of management with respect to the main business processes, which was achieved by reducing costs resulting from the automation of basic business processes (ALEKSANDROVA; VINOGRADOVA; TOKUNOVA, 2019).

The work packages defined in the modeling stage made it possible to integrate cost estimating and scheduling using a standard WBS. As a result, there was a reduction in the time taken to align designs and conduct revisions in the field. Hwang, Zhao and Yang (2019) identified some causes of the reduction in revisions with BIM also perceived in this work, such as the use of BIM throughout the design and construction phases, the enhancement of BIM knowledge through training, guidelines, and rules for BIMbased work, the development of new work processes that allow for effective BIM usage, the implementation of onsite BIM to provide workers with more accurate construction drawings and information, and a BIM manager to facilitate better BIM coordination.

Despite the definition of work packages, some field engineers still felt it necessary to break down or group the work packages defined at the beginning of the project due to changes in the work fronts. This need is because the BIM file is created gradually during the construction design stage. In the beginning, designers generally do not define any specific material for the building components; then, in the schematic design stage it is created by adding more details and non-geometric information to the conceptual design stage; and finally, an accurate model is developed in the detailed design stage (REZAEI; BULLE; LESAGE, 2019). Although in this work, the modeling had been based on the work packages, which is the lowest level of the WBS, due to the specificities throughout the life cycle, the model and the WBS needed to be updated due to the new decisions made in the field.

Although the BIM model allows to monitor the ideal progress of the construction, adjusting the project according to specific indicators in real-time (ALEKSANDROVA; VINOGRADOVA; TOKUNOVA, 2019), the delay in the insertion of data in the monitoring software negatively impacted the decision-making ability. As a result, the integration between the field and office was not working correctly.

The limitations described herein are specific to the implementation in Project 2, although some were previously discussed by Nawi, Baluch and Bahauddin (2014). Some of these benefits, e.g., the control of cost and planning targets, better integration between work packages defined in budgeting and planning, and less time spent on compatibilization and revision, have been supported by other studies, such as Isaac, Curreli and Stoliar (2017), Park and Cai (2017), and Jrade and Lessard (2015).

\section{Ease of use}

The participants assessed the ease by which they were able to use and navigate the ICSM Information Workflow tool. Table 6 presents the results of the users' evaluations.

The field teams did not assess the workflow as easy to understand as the office team, because of its lower degree of involvement in the meetings. The direct users of the software and those who received training considered the workflow easier to use. Company A publicized information by e-mail about certain aspects of the new form of work and offered training programs for the software's users. However, some of the users expressed difficulty using certain software, such as MS Project and REVIT, a finding that was justified based the minimal BIM experience by the SMEs (POIRIER; STAUB-FRENCH; FORGUES, 2015).

\section{Generalization and replicability}

The participants and researchers evaluated the generalization and replicability construct, i.e., the possibility to extend the workflow to other projects in the same company or in other companies.

Although in this study the software and tools chosen by the company studied and the reduced number of people interviewed are limitations, it was possible to highlight the ICSM Information Workflow's generalization and replicability in other contexts for each phase. The main reason for this was the standard WBS throughout the processes. And a different company can use its own code or some other classification system, such as OmniClass, Uniformat, Masterclass, and adapt it according to their needs. 
Table 6 - Evaluation of ease of use

\begin{tabular}{|c|c|c|c|}
\hline Scale & $\begin{array}{c}|c| \\
\text { I consider the activities of the } \\
\text { flow of information } \\
\text { throughout the processes to } \\
\text { be easily understood }\end{array}$ & $\begin{array}{c}\text { I consider the tools and } \\
\text { software associated with } \\
\text { the proposed workflow } \\
\text { easy to use }\end{array}$ & $\begin{array}{c}\text { The information } \\
\text { generated throughout } \\
\text { the processes is easy to } \\
\text { understand }\end{array}$ \\
\hline 1 & & & $\mathrm{~A}, \mathrm{~B}$ \\
\hline 2 & $\mathrm{~A}, \mathrm{~B}$ & $\mathrm{~A}, \mathrm{C}$ & $\mathrm{C}$ \\
\hline 3 & $\mathrm{D}$ & $\mathrm{E}$ & $\mathrm{D}$ \\
\hline 4 & $\mathrm{C}, \mathrm{E}$ & $\mathrm{D}$ & $\mathrm{E}$ \\
\hline 5 & & & \\
\hline
\end{tabular}

Note:

1 - totally disagree;

2 - partially disagree;

3 - neither agree nor disagree;

4 - partially agree; and

5 - totally agree.

A - Planning Engineer;

B - Field Engineer;

C - Intern (estimator);

D - Intern (modeler); and

$\mathrm{E}$ - Manager.

Regardless of the software used it is possible to extend the geometry and work package participatory phase to other companies. This phase is essential for the operation of the workflow because a well-defined and aligned work package among all processes facilitates the use of information by the field team and serves as the basis for improving the BIM models and simulations. Moreover, the work package definition should align with the WBS hierarchical levels in the schedule, in the model and monitoring in the field.

In the integrated BIM model elaboration phase, the 4D simulation software centralizes the 3D BIM model and planning. The role of the 4D simulation is to facilitate the visualization of the execution of the work package. Thus, it is possible to implement corrections and improvements in the work packages defined in the previous phase. The critical aspects of these first two phases are to maintain the standard WBS between the processes and to ensure the information is stored in a database (such as Excel or MS Project).

In the monitoring and control phase, as well in the integrated 3D model updating phase, the data should be sent to the field to aid in decision making at the medium- and short-term planning level. Therefore, even if the company does not have monitoring software, the data collected in the field can be inserted directly into a spreadsheet that contains the integrated data and planning and monitoring information that supports decision making with respect to the project.

\section{Conclusions}

The ICSM Information Workflow serves as a guide for modelers, estimators, and planners to implement an integrated project control, while taking into account the 3D BIM modeling, scheduling, cost estimating, and monitoring processes.

A vital requirement identified was the definition of a participatory way to elaborate the work packages in the modeling phase by involving the office and field teams to represent the way the activities are executed. This work corroborates Fan, Wu and Hun (2015), Jrade and Lessard (2015) and Umar et al. (2015) regarding a set of requirements for process integration, such as:

(a) the use of a standard WBS for all processes studied;

(b) the development of the BIM model as a function of the WBS;

(c) the providing of a BIM model to the field team to improve the visualization of planned activities; and

(d) and use a single database to centralize the information, and thereby contribute to increasing the transparency of information.

During the implementation studies of the proposed ICSM Information Workflow, some of the difficulties found in the literature regarding the use of the BIM in SMEs were evidenced, such as the lack of skills, 
knowledge and financial resources necessary for high level implementation, the lack of interoperability between different platforms and proprietary files, and the limited perception of higher levels of BIM functionality and benefits.

During the implementation process, especially related to the integration with the BIM, drawbacks were identified, such as the extensive amount of time required for interactions between departments when working with BIM technologies. Furthermore, the need to simplify processes by reducing software was evident during the study, as the majority of the programs available on the market during the study were adapted for a specific purpose according to the needs of which they were developed. Additionally, the low capital required to acquire new technologies remains a problem for SMEs. Other difficulties highlighted by the participants include the need to break down or group the work packages defined at the beginning of the project due to changes in the work fronts, thus causing weak integration between the office and the field as well as a delay in the upload of data.

In general, the main phases of the workflow system are adaptable to other projects, despite the barriers related to the number of the software products. However, certain limitations regarding the context exist, including the software and tools chosen by the company studied, the small number of people interviewed, the lack of research regarding information flow, the lack of integration among long-, medium-, and shortterm planning, and the use of spreadsheets as a database.

With respect to further studies, there is a need to evaluate the full implementation of the proposed ICSM Information Workflow in real situations and identify additional aspects for generalizing and extending the system to control different construction companies and project contexts.

\section{References}

ALASHWAL, A.; FONG, P. Empirical study to determine fragmentation of construction projects. Journal of Construction Engineering and Management, v. 141, n. 7, 2015.

ALEKSANDROVA, E.; VINOGRADOVA, V.; TOKUNOVA, G. Integration of digital technologies in the field of construction in the Russian Federation. Engineering Management in Production and Services, $v$. 11, n. 3, p. 38-47, 2019.

CARR, R. Cost, schedule, and time variances and integration. Journal of Construction Engineering and Management, v. 119, n. 2, p. 245-265, 1993.

CEREZO-NARVÁEZ, A. et al. Integration of cost and work breakdown structures in the management of construction projects. Applied Sciences, v. 10, p. 1386-1418, 2020.

CHEN, K.; LU, W. Bridging BIM and building (BBB) for information management in construction: the underlying mechanism and implementation. Engineering, Construction and Architectural Management, v. 26 n. 7, p. 1518-1532, 2019.

CHEN, S. et al. A framework for an automated and integrated project scheduling and management system. Automation in Construction, v. 35, p. 89-110, 2013.

CHO, D.; RUSSELL, J.; CHOI, J. Database framework for cost, schedule, and performance data integration. Journal of Computing in Civil Engineering, v. 27, n. 6, p. 719-731, 2013.

D'AMICO, F. et al. BIM for infrastructure: an efficient process to achieve 4D e 5D digital dimensions. In: INTERNATIONAL CONGRESS ON TRANSPORT INFRASTRUCTURE AND SYSTEMS IN A CHANGING WORLD, 2., Rome, 2019. Proceedings [...] Rome, 2019.

EASTMAN, C. et al. BIM handbook: a guide to Building Information Modeling for owners, managers, designers, engineers, and contractors. $2^{\text {nd }}$. ed. New Jersey: John Wiley\& Sons, 2011.

FAN, S. et al. Cost-based scheduling method using object-oriented approach. Automation in Construction, v. 65, p. $65-77,2016$.

FAN, S.; WU, C.; HUN, C. Integration of cost and schedule using BIM. Journal of Applied Science and Engineering, v. 13, n. 3, p. 223-232, 2015.

FISCHER, M. et al. Benefits of 3D and 4D Models for Facility Managers and AEC Service Providers. In: ISSA, R. et al. 4D CAD and visualization in construction: developments and applications. Lisse: A. A. Balkema Publishers, 2005. 
HONCHARENKO, T. et al. Reengineering of the construction companies based on bim-technology. International Journal of Emerging Trends in Engineering Research, v. 8, n. 8, 2020.

HOSSEINI, M. et al. Roadmap to mature BIM use in Australian SMEs: competitive dynamics perspective. Journal of Management in Engineering, v. 34, n. 5, 2018.

HWANG, B. G.; ZHAO, X.; YANG, K. W. Effect of BIM on rework in construction projects in Singapore: status quo, magnitude, impact, and strategies. Journal of Construction Engineering and Management, v. 145 , n. 2, 2019.

ISAAC, S.; CURRELI, M.; STOLIAR, Y. Work packaging with BIM. Automation in Construction, v. 83, p. 121-133, 2017.

ISIKDAG, U.; UNDERWOOD, J. Two design patterns for facilitating building information model based synchronous collaboration. Automation in Construction, v. 19, n. 5, p. 544-553, 2010.

JIANG, Y. et al. BIM server requirements to support the energy efficient building lifecycle. In: ISSA, R.; FLOOD. I. (ed.). Proceedings of ASCE Conference on Computing in Civil Engineering. Clearwater, 2012.

JRADE, A; LESSARD, J. An integrated BIM system to track the time and cost of construction projects: a case study. Journal of Construction Engineering, v. 2015, p. 1-10, 2015.

JRADE, A. A conceptual cost estimating computer system for building projects. Concordia, 2000. M. Sc. Thesis, Concordia University, Concordia, 2000.

MARCH, S. T.; SMITH, G. F. Design and natural science research in Information Technology. Decision Support Systems, v. 15, p. 251-266, 1995.

MONTEIRO, A.; MARTINS, J. P. A survey on modeling guidelines for quantity takeoff-oriented BIMbased design. Automation in Construction, v. 35, p. 238-253, 2013.

NADEEM, A.; WONG, A. K. D.; WONG, F. K. W. Bill of quantities with 3D views using building information modeling. Arabian Journal for Science and Engineering, v. 40, n. 9, p. 2465-2477, 2015.

NAWI, M. N. M.; BALUCH, N.; BAHAUDDIN, A. Y. Impact of fragmentation issue in construction industry: an overview. MATEC Web of Conferences, v. 9, p. 1-8, 2014.

NATIONAL BIM LIBRARY. NBS National BIM Report. 2014. Available:

https://www.thenbs.com/knowledge/bim-levels-explained. Access: 20 Sep. 2020.

O’BRIEN, E. Back to the future. Surveyors Journal, v. 5, n. 1, p. 20-21, 2015.

PARK, J.; CAI, H. WBS-based dynamic multi-dimensional BIM database for total construction as-built documentation. Automation in Construction, v. 77, p. 15-23, 2017.

POIRIER, E.; STAUB-FRENCH, S.; FORGUES, D. Embedded contexts of innovation. Construction Innovation, v. 15, n. 1, p. 42-65, 2015.

PREIDEL, C. et al. Seamless integration of common data environment access into BIM authoring applications: The BIM integration framework. In: CHRISTODOULOU, S.; SCHERER, R. (ed.). eWork and eBusiness in Architecture, Engineering and Construction. Limassol, 2016.

REMPLING, R.; KURUL, E.; OTI, A. Research roadmap for information integration in construction. Delft: CIB General Secretariat, 2019.

REZAEI, F.; BULLE, C.; LESAGE, P. Integrating building information modeling and life cycle assessment in the early and detailed building design stages. Building and Environment, v. 153, p. 158-167, 2019.

REZGUI, Y.; BEACH, T.; RANA, O. A governance approach for BIM management across lifecycle and supply chains using mixed-modes of information delivery. Journal of Civil Engineering and Management, v. 19, n. 2, p. 239-258, 2013.

SANTOS, M. C. F.; COSTA, D. B.; FERREIRA, E. A. M. Conceptual framework for integrating cost estimating and scheduling with BIM. In: SANTOS, E. T.; SCHEER, S. (ed.). Proceedings of the 18th International Conference on Computing in Civil and Building Engineering. 2021.

SARIDAKI, M.; PSARRA, M.; HAUGBØLLE, K. Implementing lifecycle costing: data integration between design models and cost calculations. Journal of Information Technology in Construction, v. 24, p. 14-32, 2019. 
SCHEER, S. et al. On-site BIM model use to integrate $4 \mathrm{~d} / 5 \mathrm{~d}$ activities and construction works: a case study on a Brazilian low income housing enterprise. In: INTERNATIONAL CONFERENCE ON COMPUTING IN CIVIL AND BUILDING ENGINEERING, Orlando, 2014. Proceedings [...] Orlando, 2014.

SOLIHIN, W.; EASTMAN, C.; LEE, Y. C. A framework for fully integrated building information models in a federated environment. Advanced Engineering and Informatics, v. 30, n. 2, p. 168-189, 2016.

UMAR, U. et al. 4D BIM application in AEC industry: Impact on integrated project delivery. Research Journal of Applied Sciences, Engineering and Technology, v. 10, p. 547-552, 2015.

VAISHNAVI, V.; KUECHLER, W. Design science research methods and patterns: innovating information and communication technology. $2^{\text {nd }}$. ed. United Kingdom: CRC Press, 2015.

VIDALAKIS, C.; ABANDA, F. H.; OTI, A. H. BIM adoption and implementation: focusing on SMEs. Construction Innovation, v. 20, n. 1, p. 128-147, 2020.

WANG, K. C. et al. Applying building information modeling to integrate schedule and cost for establishing construction progress curves. Automation in Construction, v. 72, p. 397-410, 2016.

WANG, Y. et al. Collaborative relationship discovery in BIM project delivery: a social network analysis approach. Automation in Construction, v. 114, p. 1-19, 2020.

XU, X.; MA, L.; DING, L. A framework for BIM-enabled life-cycle information management of construction project. International Journal of Advanced Robotic Systems, v. 11, n. 8, 2014.

Mirian Caroline Farias Santos

Programa de Pós Graduação em Engenhara Civil | Universidade Federal da Bahia | Rua Aristides Novis, 02, $5^{\circ}$ andar, Federação | Salvador - BA - Brasil | CEP 40210-630 | E-mail: miriancfarias@gmail.com

Dayana Bastos Costa

Departamento de Construção e Estruturas, Programa de Pós Graduação em Engenhara Civil | Universidade Federal da Bahia | Tel.: (71) 3283-9731 | E-mail: dayanabcosta@ufba.br

\title{
Emerson de Andrade Marques Ferreira
}

Programa de Pós Graduação em Engenhara Civil | Universidade Federal da Bahia | E-mail: ferreira.eam@gmail.com

\author{
Ambiente Construído \\ Revista da Associação Nacional de Tecnologia do Ambiente Construído \\ Av. Osvaldo Aranha, $99-3^{\circ}$ andar, Centro \\ Porto Alegre - RS - Brasil \\ CEP $90035-190$ \\ Telefone: +55 (51) 3308-4084 \\ Fax: +55 (51) 3308-4054 \\ www.seer.ufrgs.br/ambienteconstruido \\ E-mail: ambienteconstruido@ufrgs.br
}

